\title{
Adaptive Management of Cultivated Land Use Zoning Based on Land Types Classification: A Case Study of Henan Province
}

\author{
Yanan Liu ${ }^{1} \oplus$, Kening $\mathrm{Wu}^{1,2, *}$, , Xiaoliang $\mathrm{Li}^{1}{ }^{1}, \mathrm{Xiao} \mathrm{Li}^{1} \oplus$ and Hailong Cao ${ }^{3}$ \\ 1 College of Land Science and Technology, China University of Geosciences, Beijing 100083, China; \\ yananliu@cugb.edu.cn (Y.L.); 2012170035@cugb.edu.cn (X.L.); 3012200015@cugb.edu.cn (X.L.) \\ 2 Key Laboratory of Land Consolidation, Ministry of Natural Resources, Beijing 100035, China \\ 3 China Geo-Engineering Corporation, Beijing 100093, China; caohl199001@163.com \\ * Correspondence: wukening@cugb.edu.cn
}

Citation: Liu, Y.; Wu, K.; Li, X.; Li, X.; Cao, $H$. Adaptive Management of Cultivated Land Use Zoning Based on Land Types Classification: A Case Study of Henan Province. Land 2022, 11, 346. https://doi.org/10.3390/ land11030346

Academic Editors: Eugene Ezebilo and Patrice Savadogo

Received: 25 January 2022

Accepted: 23 February 2022

Published: 25 February 2022

Publisher's Note: MDPI stays neutral with regard to jurisdictional claims in published maps and institutional affiliations.

Copyright: (c) 2022 by the authors. Licensee MDPI, Basel, Switzerland. This article is an open access article distributed under the terms and conditions of the Creative Commons Attribution (CC BY) license (https:// creativecommons.org/licenses/by/ $4.0 /)$.

\begin{abstract}
Cultivated land serves as an important resource to ensure national food security, and how to allocate cultivated land reasonably and sustainably is an urgent problem that needs to be solved at present. Therefore, identifying land cultivability from the basic attributes of land and carrying out adaptive management measures in different zones is an effective way. Taking Henan province as a case study area, we proposed a research scheme for the adaptive management of cultivated land use zoning based on land types. First, a three-level land types classification system at the provincial level was established from five aspects—climate, topography, geology, soil properties, and hydrological conditions - and then Henan was divided into 39 first-level units, 4358 second-level units, and 6446 third-level units. On this basis, the changes in the status of land use in Henan province from 2009 to 2018 were analyzed from the four aspects of cultivated land utilization, population, grain yield, and GDP. The amount of cultivated land decreased, while the economy grew, the population increased, and grain yield increased, indicating that it is urgent to pay attention to the problem of cultivated land, and it is necessary to identify the potential space of cultivated land and manage and protect it reasonably. Based on the land types, evaluation of cultivability was carried out, the results showed that the degree of cultivability from high to low presented a transitional spatial distribution state from the east and the south to the middle, the north, and the west. Then superimposing the status of land use, six types of protection and management zones were proposed, and management suggestions were adaptively analyzed. The ideas and methods proposed in this study can be adapted to manage and utilize cultivated land from the perspective of sustainable utilization, which is of great significance for ensuring food security.
\end{abstract}

Keywords: land type; cultivability evaluation; land use zoning; adaptive management; sustainable management

\section{Introduction}

Cultivated land, as a material basis for human survival and development, is the key to solving food security issues. According to the report "The State of the World's Land and Water Resources for Food and Agriculture in 2021", more than 95\% of the food produced in the world comes from land resources, but there is very little high-yield cultivated land available for further development [1]. "The State of Food Security and Nutrition in the World 2021" report estimates that in 2020, there are 720 811 million people facing hunger in the world, and nearly 2.37 billion people do not have access to sufficient food, which is enough to indicate that there is a moderate or severe global food insecurity problem [2]. At the same time, in the context of the normalization of the global COVID-19, how to ensure food security has become a hot topic in the field of land science [3-5].

Since the implementation of China's reform and opening-up policy, population growth, industrialization, urbanization, and the impact of globalization have intensified the contradiction between humans and land resources, and the decline in the quantity and quality 
of cultivated land has seriously threatened the national food security and the harmonious development of human society [6,7]. Chinese President Xi Jinping pointed out that "cultivated land is the lifeblood of grain production" and "we must ensure national food security and firmly hold the rice bowl of the Chinese in our own hands". The "Proposals of the Central Committee of the Communist Party of China on Formulating the Fourteenth Five-Year Plan for National Economic and Social Development and the Long-Term Goals for 2035" pointed out that it is necessary to adhere to the strictest cultivated land protection system and implement the strategy of "grain storage in land and technology". The Central Economic Work Conference in December 2020 pointed out the need to resolutely curb the phenomenon of "non-agriculturalization" and "non-grain production" and standardize the balance of cultivated land between occupation and compensation. According to the third national land survey, at the end of 2019, the national cultivated land area was 1.918 billion $\mathrm{mu}$. Compared with the second survey in 2009, the cultivated land area has been reduced by 113 million $\mathrm{mu}$, while the per capita cultivated land resource area is only $1.36 \mathrm{mu}$, which is less than half of the world average, and the cultivated land area is decreasing year by year $[8,9]$. China's reserve cultivated land is insufficient, in the process of balance between cultivated land occupation and supplement, there may be phenomena of high-quality cultivated land used for non-agricultural construction, poor-quality land used for farming, and the cultivated land safety issue, which is difficult to address [10].

With the continuous increase in population and rapid social and economic development, the demand for food has threatened the quantity and quality of cultivated land. Under the concept of sustainable development, we should pay attention to the maintenance of the ecological environment of cultivated land. Therefore, the development method based on nature is the current trend, which prompts the need for effective cultivated land suitability methods to achieve global food security goals and ensure sustainable agriculture development [11,12]. The study of comprehensive regional hydrothermal conditions, landform types, soil types, and other natural geographical elements of land type divisions essentially comprises the analysis and induction of land essential elements $[13,14]$, which is an effective means to reflect the essential attributes of land resources and is also a reasonable way to manage and plan land resources. It is of great significance to the healthy development of the region and the construction of ecological civilization [15,16]. The evaluation of cultivability based on the land types can identify the land suitable for farming from the perspective of natural context and then optimize the spatial distribution of the existing cultivated land. It is an effective means to adjust the current mismatch of land resources and to achieve high-quality development goals.

Therefore, it is necessary to establish a cultivability evaluation system based on land types classification. Through the division of land types, the basic natural attributes and composition structure can be analyzed, and then the evaluation system of cultivability can be established to identify the potential production space of cultivated land resources to optimize the current layout of land use, which has a certain reference significance for the national cultivated land protection and the implementation of the strategy of "grain storage in land and technology".

\section{Literature Review}

Before the early 19th century, many foreign scholars successively established the research framework of geospatial unit classification based on the characteristics of natural environment, which laid a good research foundation for the research of comprehensive classification systems [17]. In terms of this type of research, there is a trend from single factor division to comprehensive factors division. Especially after the word "ecosystem" was put forward [18], this idea was more obvious in the practice of land type divisions. In 1986, the FAO and other departments proposed to establish the global 1:1 million soil and terrain digital database [19], a three-level soil terrain unit divided by landform, soil types, and geology. Subsequently, in order to identify the structure and function of the system, different scholars and institutions established corresponding and more comprehensive classification 
systems, such as the land resource hierarchical classification system [20], ecological land classification system [21], etc., but there are some differences in the classification levels and basis of different classification systems. The research on land types classification in modern China was gradually carried out based on the work of the natural zoning in the late 1950s, introducing the landscape classification thought of the former Soviet Union and Germany and the comprehensive system classification ideas of the United Kingdom, the United States, and Australia [22]. In the 1970s and 1980s, certain research results were formed, and China's 1:1 million land types classification system and mapping standards were established [23,24]. However, since the mid-1980s, domestic research on land types has gradually slowed down and the enthusiasm has decreased $[25,26]$, and there has not been breakthrough research on the small and medium level. With the development of the times and the deepening of land development, our understanding of the attributes of land is also changing, and currently, the concept of the Earth Critical Zone [27] and its classification $[28,29]$ has an important impact on the research of land types classification. Therefore, it is necessary to further study the classification of small- and medium-level land types under the new situation.

Agricultural suitability analysis mainly has two aspects: one is for specific uses and the other is for specific crops [30]. Generally, the former serves for the macro-scale land planning, while the latter is more practical on the micro-scale such as farmland and field [31,32]. In 1976, a recognized land suitability classification system was established in "A framework for land evaluation" formulated by the Food and Agriculture Organization of the United Nations (FAO), which was divided into four categories: orders, classes, subclasses, and units. Firstly, land suitability orders can indicate whether the land is suitable or not, if suitable then according to the degrees of suitability, can be divided into four classes: highly suitable, moderately suitable, marginally suitable, and not suitable, which can be divided into two classes-currently not suitable and permanently not suitablewhere the subclasses can reflect the kinds of limitations and the units are subdivisions of a subclass [33]. The method of FAO has promoted the evaluation of land suitability in China and then the "1:1 million land resources map in China" was compiled [34]. In the early 21st century, the existing land development reached a certain level, so it is not necessary to drastically change the existing use to optimize land use issues, but rather to focus on the management methods of over-developed land. Therefore, FAO revised the framework for land evaluation in 2007, elaborated the evaluation process of land suitability, and took social economy and management measures as the key factors [30]. In the evaluation of crop suitability, the evaluation target is generally based on specific crops. According to the needs of crop growth, considering the suitability of the natural, social, and economic conditions of the land, and then determine suitable crops $[35,36]$. For the suitability evaluation of specific uses, especially farming, the natural characteristics of the land and socio-economic and human management factors are all factors that need to be considered in the evaluation [37,38]. In terms of evaluation methods, with the application of GIS technology, many application systems and models have been developed, such as SYMAP and GRID system [39], and Genetic Algorithm, CA model, matter element model, etc. [40-42].

From the existing research literatures, the land types classification in China needs further in-depth study at the provincial level according to the current actual needs and development trend. For the evaluation of suitability for specific purposes, the traditional evaluation method is to select evaluation indicators to assess the suitability of cultivated land based on the current status of the use of cultivated land; however, it is only a judgment of the current status of use, and cannot know the land which is suitable for farming. The cultivated land resources are scarce, food security is serious, and we should pay attention to sustainable development; it is necessary to analyze the potential space of cultivated land based on the natural conditions. Therefore, this study in Henan province, one of the major food-producing province in China, was taken as a case study and carried out from the following three steps (Figure 1): (1) according to the existing research, we construct 
the provincial-level land types classification system; (2) based on the classification of land types, the evaluation system of cultivability can be established to calculate the degree of land suitable for cultivation in Henan; and (3) the calculated results are compared with the current situation of land use, the adjustable land use types are identified and divided into different management zones, and then the corresponding management measures are formulated. Finally, the cultivated land zoning adaptive management scheme based on land types is formed. The research results can provide ideas and reference for the potential spatial identification and optimal utilization layout of cultivated land resources.

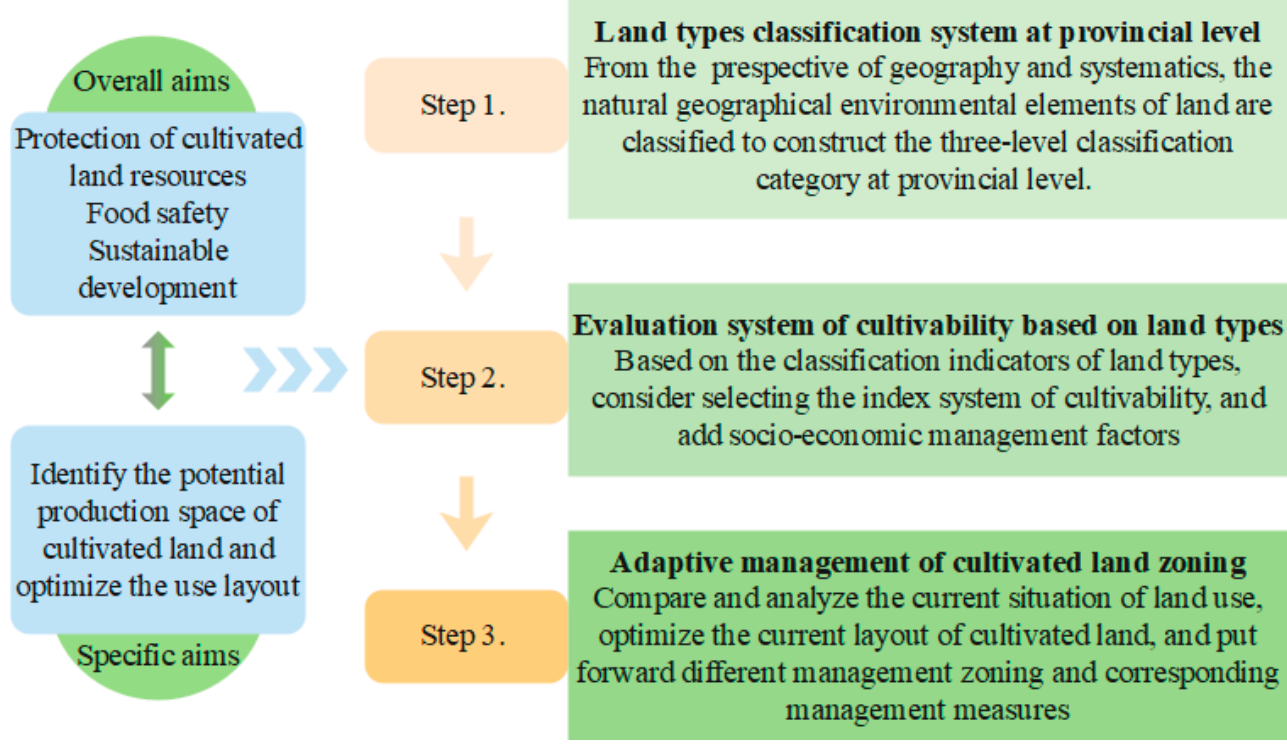

Figure 1. The research steps framework.

\section{Data and Methodology}

\subsection{Study Area}

Henan Province $\left(31^{\circ} 23^{\prime} \sim 36^{\circ} 22^{\prime} \mathrm{N}, 110^{\circ} 21^{\prime} \sim 116^{\circ} 39^{\prime} \mathrm{E}\right)$ is located in the middle eastern part of China (Figure 2), with high elevations in the west and low in the east. The total area is $165,700 \mathrm{~km}^{2}$, influenced by the unique geotectonic activities, the landforms are complex and diverse, and the plains and basins, mountains, and hills in the territory account for $55.70 \%, 26.60 \%$, and $17.70 \%$ of the total area, respectively. Henan has a warm temperate/subtropical zone and humid/semi-humid monsoon climate. The annual average temperature is $12-16^{\circ} \mathrm{C}$ and the annual average precipitation is about $600-1200 \mathrm{~mm}$. There are many soil types, showing obvious horizontal and vertical zonal distribution characteristics. Good topography and climate provide favorable conditions for Henan to become one of the major grain-producing provinces in China. The ratio of cultivated land area was $49.21 \%$, while the ratio of construction land area was $16.09 \%$, and the forest coverage rate was $24.53 \%$ at the end of 2018 . Henan province has a population of 109.06 million and the Gross Domestic Product was 485.56 billion yuan in 2018. However, the cultivated land area decreases year by year; thus, it is urgent to identify the potential space of quantity and quality of cultivated land resources, optimize the utilization space of cultivated land resources, and take reasonable land use measures to maintain food security at present. 
(a)

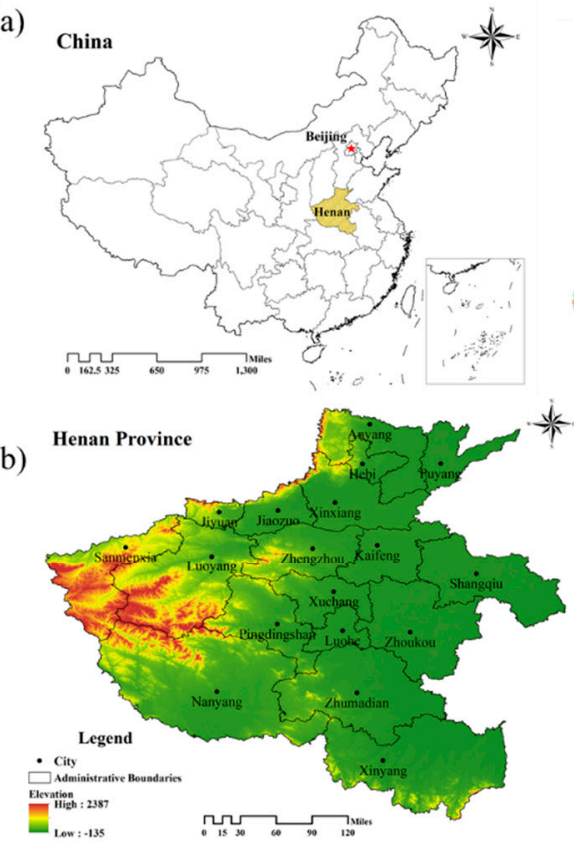

(c)

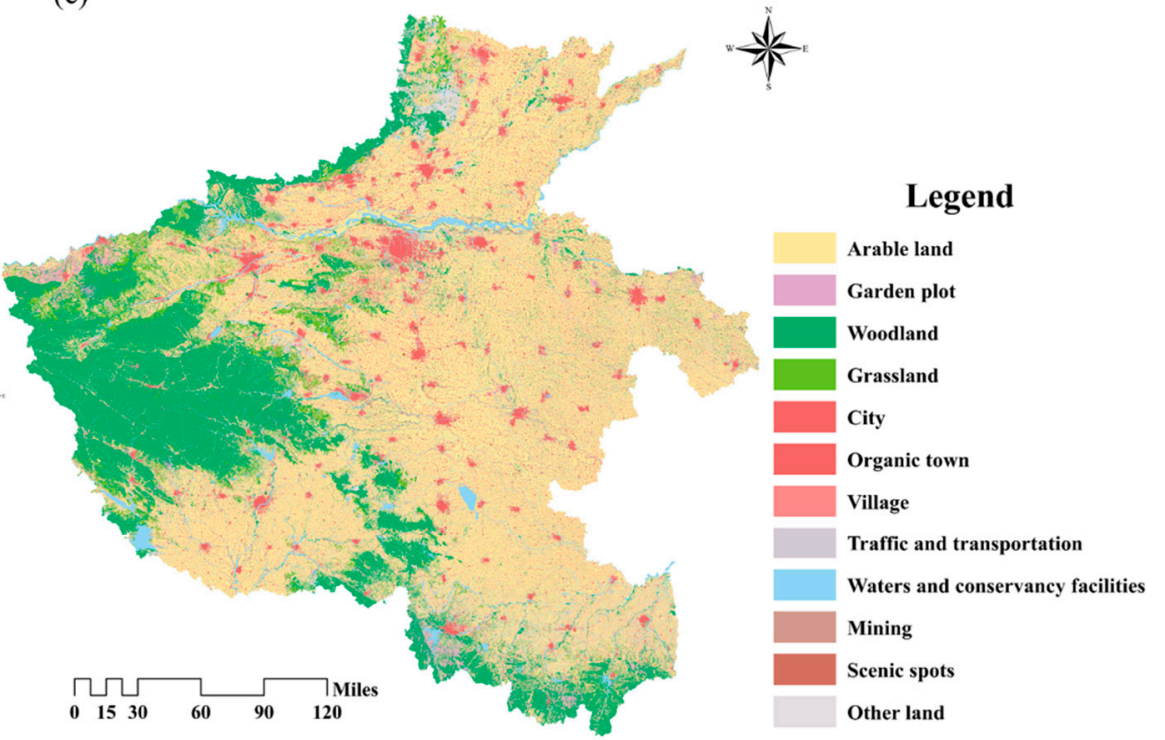

Figure 2. Study area overview: (a) the location of Henan province in China, (b) elevation of Henan province, and (c) land use of Henan province in 2018.

\subsection{Land Types Classification}

Land is a natural economic complex formed by the interaction of climate, geology, geomorphology, hydrology, soil, vegetation, and other factors in a certain section of the earth's surface and affected by past and current human activities. It is a comprehensive system connected with the surrounding natural and human environment through material and energy interaction $[43,44]$. Classification is to divide things into different groups according to certain rules or purposes based on their attributes and characteristics. It is an effective tool for combing and analyzing things relationships and comparing vertical and horizontal differences [45]. To specifically describe land types for practice, land types classification based on the taxonomic principles can be described as the most direct method. From the perspective of geography, land types are comprehensively and systematically affected by the occurrence, development, and evolution of natural geographic elements. The main content of its research is to reveal the formation, characteristics, and structure of natural elements in a certain geographical area, reflecting the law of development and succession $[22,46]$. From the perspective of systems theory, the land natural system is an organic whole with a certain structure and functions formed by the interaction of two or more elements. The various elements are not mechanical or simple combinations with each other; however, it is a combination of elements formed through complex connection relations. Both internal and external have relevance and hierarchical structure, thus showing certain patterns, principles, and laws, and each element does not exist in isolation. Each element has a certain position in the system and plays a specific role [47]. Therefore, the classification of land types should have a certain level of hierarchy. Based on the relevant research, in this study, according to the systematic and scientific principles, dominant principles, regional differentiation laws, practical principles, etc. [14,48,49], as well as the top-down structure of the hierarchy, a three-level classification category of the provincial-level land types classification system (Figure 3) was built from the five aspects of climate, topography, geology, soil properties, and hydrological conditions. 


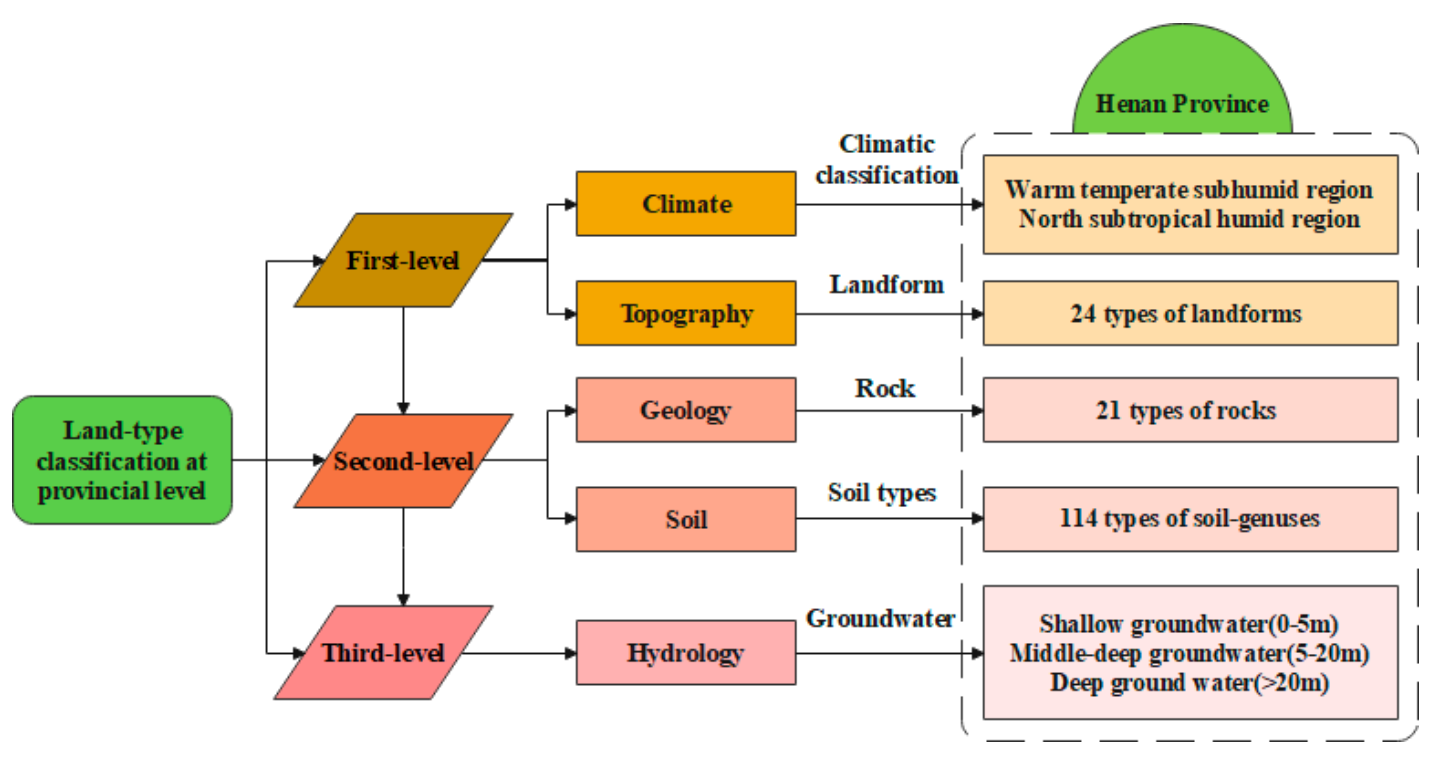

Figure 3. Land types classification system at the provincial level.

First-level classification: Climate effects on the large and medium spatial scale are mainly solar radiation, which is direct and lasting. Temperature and precipitation in regional hydrothermal conditions affect the synthesis, decomposition, migration, and flow of surface materials [50]. During the formation of topography, due to the difference in surface forces, the surface morphology fluctuates greatly, and then hydrothermal conditions are redistributed [51]. Therefore, the combined effect of climate and topography leads to regional differences. Climate zone and landform types are selected as the dominant classification factors.

Second-level classification: The composition of surface material is complex. After long-term and complicated geological changes, the distribution of rocks is different. The weathering product formed on the surface by the processes of weathering, migration, and accumulation, as well as physical, chemical, and biological processes, is the parent material, which is the material basis for the formation of soil [52]; in different spatial locations, climate, topography, soil-forming parent material, lithology, and other factors synergistically work together, and then soil types show different spatial distribution [53]. Therefore, rock types and soil types are the leading classification factors at this level.

Third-level classification: Water resources have an important impact on regional hydrothermal conditions, topography, lithology, soil, and other environmental conditions. They are closely related to the growth of surface animals and plants, and also affect land use methods and direction [54]. The distribution of surface water is closely related to precipitation in climatic elements [55]. Therefore, the depth of groundwater is selected as the leading classification factor in this level.

\subsection{Evaluation of Cultivability}

\subsubsection{Evaluation Thought}

From the perspective of planning, land suitability evaluation means that when land is used for specific purposes, such as agriculture, forestry, animal husbandry, etc., land suitability is graded according to the natural conditions, which involves the assessment of the climate, topography, soil, and hydrology of the environment [56,57]. Nowadays, most land resources have been fully developed, the current evaluation of cultivability is to optimize the existing problems of land use according to the current development status of land use, which should not only consider natural conditions, but also social economy and management mode. Therefore, based on the evaluation process in the "land evaluationtowards a revised framework" and some relevant research [30,58,59], the cultivability evaluation thought map in this study is listed (Figure 4). 


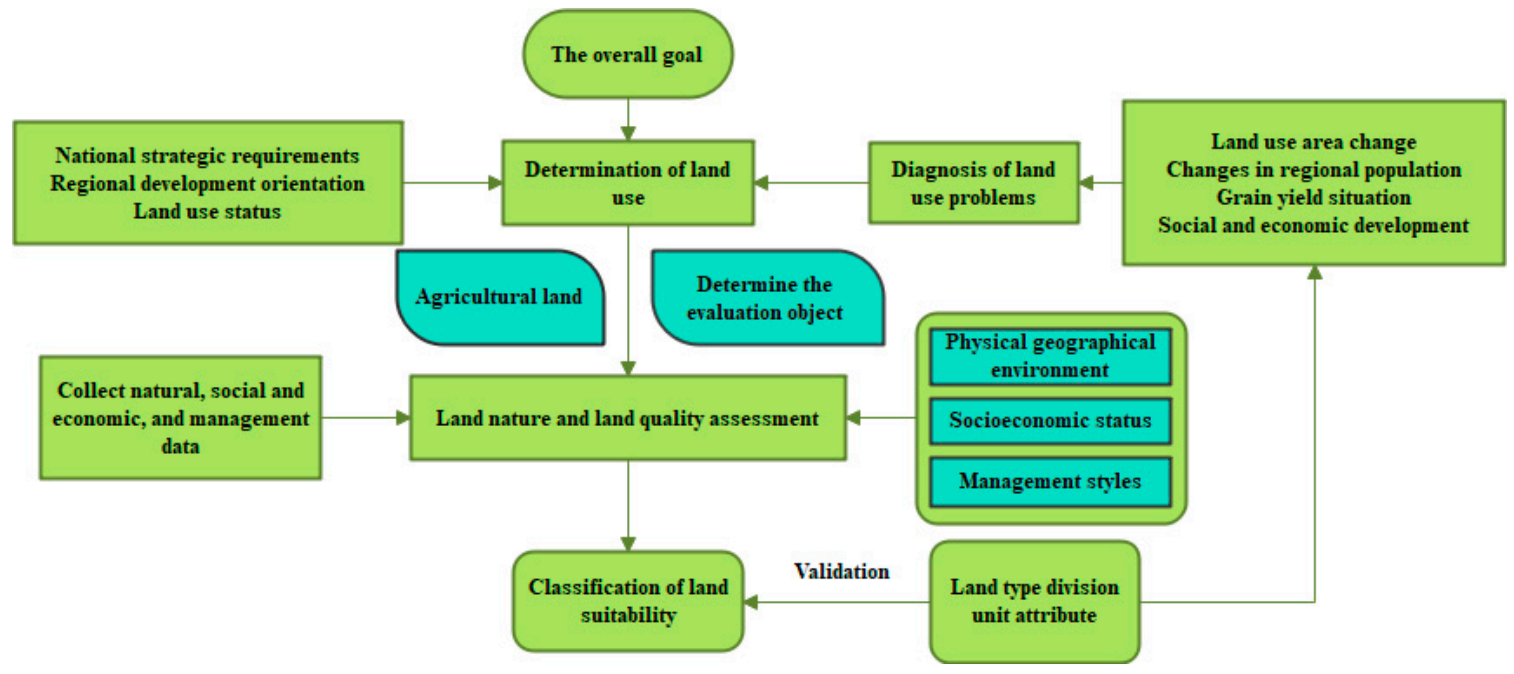

Figure 4. Cultivability evaluation thought map.

In this study, Henan province, a major grain-producing province in China that plays an important role in China's food security, was taken as the study area. According to the overall goal of this study, under the premise of national strategic requirements and Henan's development orientation, the problems existing in the current land use situation were diagnosed from cultivated land use area change, population, food production, and social and economic development. Then, the degree of cultivability was evaluated from the natural geographical environment, social economy, and management mode, and then the results can be verified based on the land types.

\subsubsection{Selection of Evaluation Indexes}

Many factors affect the cultivability of land; it is often the leading factors that play a key role, and the selected factor demonstrates a restrictive factor in land use, which needs to meet certain requirements. There should be distinctions between indicators, and the characteristics of different units can be shown through evaluation. Therefore, the indicators should be comparable, representative, and meaningful and the process of selecting should follow the principles of dominance, systematic processes, stability, standardization, and regionality $[60,61]$. Under the guidance of the above evaluation thought, we referred to the relevant research $[30,62-64]$ through expert consultation based on the factors of land types classification, and we selected the index system from six aspects of climate conditions, namely topography, soil properties, hydrological conditions, and social economic and management methods (Table 1). Climatic conditions and topography are the reflections of the overall hydrothermal conditions of the region. Based on the consideration of farming purposes, the factors of effective accumulated temperature $\left(\geq 10^{\circ} \mathrm{C}\right)$ and annual average precipitation, elevation, and slope were selected. Soil property is the carrier directly related to the growth of crops, and its fertility status is related to the yield of crops, so the factors of soil texture, soil depth, soil organic carbon, soil available water capacity, gravel content, bulk density, soil $\mathrm{pH}$, and cation exchange capacity (CEC) were selected. Groundwater depth was selected as the indicator of hydrological conditions. Owing to the difficulty in acquiring data and the purposes of agriculture, the agricultural employment rate, the proportion of the primary industry output value, and distance from the main road were selected as the indicator of the social economy and tillage system, and irrigation conditions and drainage conditions were selected for management. 
Table 1. Grading standard for indicators of cultivability evaluation.

\begin{tabular}{|c|c|c|c|c|c|c|c|c|c|}
\hline Factor & Evaluation Indicator & 100 & 85 & 75 & 60 & 45 & 25 & $\begin{array}{c}\text { Indicator } \\
\text { Weight }\end{array}$ & Factor Weight \\
\hline \multirow{2}{*}{$\begin{array}{l}\text { Climatic } \\
\text { conditions }\end{array}$} & $\begin{array}{l}\text { Effective accumulated } \\
\text { temperature } \\
\left(\geq 10^{\circ} \mathrm{C}\right) /{ }^{\circ} \mathrm{C}\end{array}$ & $\geq 4440$ & $(4440,4250]$ & $(4250,4020]$ & $(4020,3750]$ & $(3750,3210]$ & $<3210$ & 0.0549 & \multirow{2}{*}{0.1098} \\
\hline & $\begin{array}{c}\text { Annual average } \\
\text { precipitation } / \mathrm{mm}\end{array}$ & $\geq 635$ & $(635,609]$ & $(609,585]$ & $(585,565]$ & $(565,545]$ & $<545$ & 0.0549 & \\
\hline \multirow{2}{*}{ Topography } & Elevation $/ \mathrm{m}$ & $<100$ & {$[100,300)$} & {$[300,500)$} & {$[500,800)$} & {$[800,1500)$} & $\geq 1500$ & 0.0454 & \multirow{2}{*}{0.1158} \\
\hline & Slope $/^{\circ}$ & $<2$ & {$[2,6)$} & {$[6,15)$} & & {$[15,25)$} & $\geq 25$ & 0.0704 & \\
\hline \multirow{6}{*}{ Soil property } & Soil depth/cm & $\geq 150$ & {$[100,150)$} & & {$[60,100)$} & {$[30,60)$} & $<30$ & 0.0489 & \multirow{6}{*}{0.5447} \\
\hline & Soil organic carbon $/ \%$ & $\geq 2.0$ & $(2.0,1.2]$ & & $(1.2,0.6]$ & $(0.6,0.2]$ & $<0.2$ & 0.1098 & \\
\hline & $\begin{array}{l}\text { Soil available water } \\
\text { capacity } / \%\end{array}$ & 150 & 125 & 100 & 75 & 50 & 15 & 0.0657 & \\
\hline & Gravel content/\% & $\leq 2$ & $(2,5]$ & $(5,8]$ & $(8,11]$ & $(11,15]$ & $>15$ & 0.0572 & \\
\hline & Bulk density $/\left(\mathrm{g} \cdot \mathrm{cm}^{-3}\right)$ & {$[1,1.25)$} & {$[1.25,1.35)$} & & {$[1.35,1.45)$} & {$[1.45,1.55)$} & $\geq 1.55$ or $<1$ & 0.0456 & \\
\hline & Soil pH & {$[6.0,7.5)$} & & {$[5.5,6.0)$ or $[7.5,8.5)$} & & {$[5.0,5.5)$ or $[8.5,9.0)$} & $\geq 9.0$ or $<5.0$ & 0.0699 & \\
\hline $\begin{array}{l}\text { Hydrological } \\
\text { conditions }\end{array}$ & Groundwater depth/m & $>20$ & & {$[5,20]$} & & $(0,5)$ & & 0.0325 & 0.0325 \\
\hline \multirow{3}{*}{ Social economy } & $\begin{array}{c}\text { Agricultural } \\
\text { employment rate }\end{array}$ & $>1.78$ & $(1.05,1.78]$ & $(0.63,1.05]$ & $(0.43,0.63]$ & $(0.16,0.43]$ & $(0.00,0.16]$ & 0.0335 & \multirow{3}{*}{0.0939} \\
\hline & $\begin{array}{l}\text { The proportion of the } \\
\text { primary industry output } \\
\text { value/\% }\end{array}$ & $>19.90$ & $(14.95,19.90]$ & $(9.87,14.95]$ & $(5.92,9.87]$ & $(2.46,5.92]$ & $(0.00,2.46]$ & 0.0242 & \\
\hline & $\begin{array}{l}\text { Distance from main } \\
\mathrm{road} / \mathrm{m}\end{array}$ & $>0.5$ & & $(0.2,0.5]$ & & $(0.1,0.2]$ & $\leq 0.1$ & 0.0362 & \\
\hline \multirow{3}{*}{ Management } & Tillage system & $\begin{array}{c}\text { Three harvests } \\
\text { a year }\end{array}$ & $\begin{array}{l}\text { Two harvests } \\
\text { a year }\end{array}$ & & $\begin{array}{l}\text { Three harvests } \\
\text { two years }\end{array}$ & One harvest a year & & 0.0142 & \multirow{3}{*}{0.1033} \\
\hline & Irrigation conditions & Fully satisfied & & $\begin{array}{l}\text { Basically } \\
\text { satisfied }\end{array}$ & Generally satisfied & & No irrigation & 0.0525 & \\
\hline & Drainage conditions & Excellent & & Good & Ordinary & Poor & Very poor & 0.0366 & \\
\hline
\end{tabular}




\subsubsection{Evaluation Method}

In this study, the vector patch formed by superimposed each indicator datum was taken as the evaluation units. The multi-index comprehensive evaluation method was used to establish the cultivability evaluation model. The calculation formula is as follows:

$$
S_{i}=\sum_{j=1}^{n} F_{i j} W_{i j}
$$

where $S_{i}$ is the cultivability index of the $i$-th evaluation unit, $F_{i j}$ is the grading score of the $j$-th indicator of the $i$-th evaluation unit, and $W_{i j}$ is the weight of the $j$-th indicator of the $i$-th evaluation unit.

Due to the different dimensions of various indicators, they are not comparable, and the size or scope of each indicator directly affects the degree of cultivability. Therefore, the grading standard of each indicator was determined according to the relevant standards [65-67]. The weight was determined by the analytic hierarchy process and expert consultation method (Table 1). According to the calculation results of the above formula, the suitable categories were divided into four categories: highly suitable (85 100), moderately suitable (75 85), marginally suitable (65 75), and unsuitable (0 65).

\subsection{Adaptive Management Scheme for Cultivated Land Use Zoning}

According to "land evaluation-towards a revised framework" [30], this study followed the rules of avoiding drastic changes in existing construction as far as possible, and the evaluation results were used for the purpose of optimizing the current use. Based on the classification of land types, the calculation results of the cultivability evaluation were superimposed on the current land use types of Henan province. Taking cities as statistical units, the areas which are highly suitable and have current use for cultivation were divided into conservation areas. The areas, moderately suitable or marginally suitable have current use for cultivation, were divided into moderate improvement areas. The areas, unsuitable and have current use for cultivation were divided into comprehensive output areas. While the areas that are highly suitable, moderately suitable, and marginally suitable but do not have current use for cultivation were divided into priority input areas, key remediation areas, and comprehensive remediation areas, respectively, considering that the current land use can be adjusted. Combined with the basic database of land types and the evaluation results, the adaptive management suggestions for different zones can be put forward.

\subsection{Data Source and Processing}

In this study, the land types database of Henan was used as the basic evaluation database, and then the indicators were selected to evaluate the cultivability of land. Finally, the land use status of Henan province was superimposed to optimize and manage the zoning of land use misallocation. The data used for land types classification were the existing classified data, and the indicator data were used for cultivability evaluation. The climate zone data were from China's climate zone map from 1981 to 2010 [68]. Effective accumulated temperature $\left(\geq 10^{\circ} \mathrm{C}\right)$ and annual average precipitation were from the China Meteorological Dataset (500 m grid) of Resource and Environment Science and Data Center of the Chinese Academy of Sciences (https:/ /www.resdc.cn/, accessed on 20 May 2021). Landform types were from the database of the classification system of digital land geomorphology of 1:1 million in China [69]. Elevation and slope data were derived from the digital elevation model (DEM) (30 m grid), which was from the Geospatial Data Cloud (https:/ /www.gscloud.cn/, accessed on 20 May 2021). The data of rock types and soil types were derived from the National Earth System Science Data Center (http://www.geodata.cn/, accessed on 25 May 2021). Soil attribute data, such as soil texture, soil organic carbon content, and soil depth, were from Harmonized World Soil Database (HWSD) (1 km grid), and groundwater depth and groundwater model prediction data were obtained from Water-Related Knowledge Service System (http:/ / mwr.ckcest.cn/, 
accessed on 30 May 2021) [70]. The data of agricultural employment rate, primary industry output value, farming system, irrigation guarantee rate, and drainage conditions were derived from Henan Statistical Yearbook. The distance from the main road was obtained by establishing buffer space analysis based on ArcGIS software. Land use status data were from the land use change database of Henan in 2018.

\section{Results}

\subsection{Analysis of Land Types Classification in Henan Province}

According to the land types classification system at the provincial level, the climatic zones and first-level landform types were superimposed and intersected, and the first-level units were obtained by merging the same attribute patches. Then the rock types and soil types were superimposed to obtain the second-level units. Based on the first two, the groundwater depth was superimposed to obtain the third-level units. Finally, Henan province was divided into 39 first-level units, 4358 second-level units, and 6446 third-level units (Figure 5).

Among the first-level units, the uplift/erosion flow low-altitude plain in the northern subtropical humid region (C041T11130) accounts for the largest area ratio of Henan (36.44\%), followed by the uplift/erosion flow low-altitude plain in the warm temperate semi-humid region (C032T11130), which accounts for $16.35 \%$ of the area ratio of Henan; these two occupy more than half of the Henan, with rich distribution and high complexity. The area ratio of the uplift/erosion low-altitude platform in the northern subtropical humid region (C041T21130) and uplift/erosion low-altitude undulating mountain in the warm temperate semi-humid region (C032T52130) accounted for more than 5.00\% of Henan, respectively, while the former has high occurrence frequency and rich distribution.

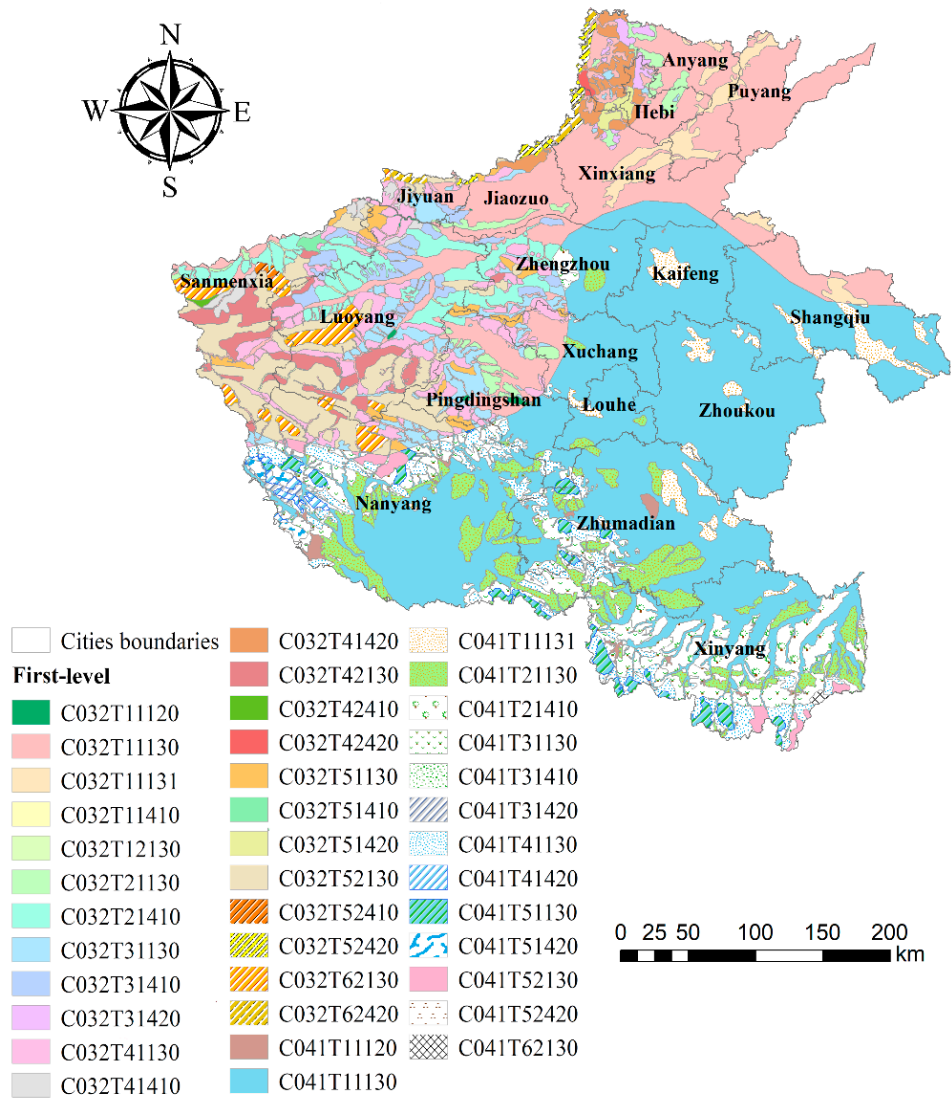

Figure 5. Cont. 


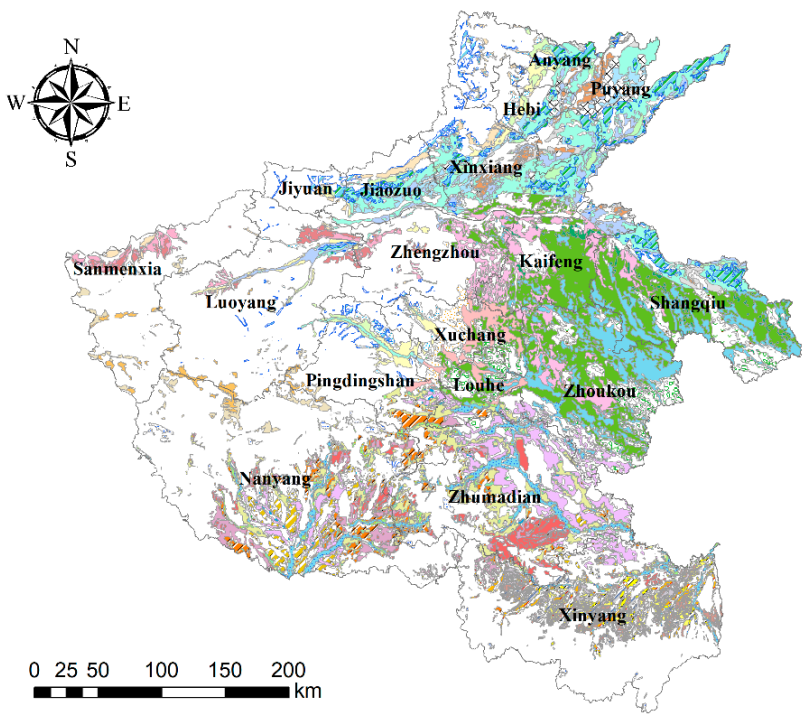

\begin{tabular}{|c|c|c|c|}
\hline Cities boundaries & T11130GUFSG112 & WHA C041T11130GUESG078 & C041T11130GULSG014 \\
\hline Second-level & C032T11131GUFSG091 & C041T11130GUF/ULSG090 & C041T11130GULSG055 \\
\hline C032T11130GUESG060 & 2T11131GUFSG103 & C041T11130GUF/ULSG098 & Fo41T11130GULSG090 \\
\hline Da C032T11130GUESG061 & C032T21410GUESG067 & C041T11130GUFSG004 & $\because$ C041T11131GUFSG091 \\
\hline C032T11130GUES & C032T21410GUESG072 & C041T11130GUFSG055 & C041T21130GUESG055 \\
\hline C032T11130GUFSG004 & C032T52130GIA ISG032 & C041T11130GUFSG082 & C041T21130GUESG066 \\
\hline C032T11130 & $2 \mathrm{~T} 52130 \mathrm{GI} \wedge 1 \mathrm{SG} 034$ & 1130GUFSG091 & C041T21130GUESG069 \\
\hline C032T11130GUFSG083 & 11130 GUESG013 & C041T11130GUFSG093 & C041T21410GUESG073 \\
\hline C032T11130GUFSG091 & C041T11130GUESG055 & C041T11130GUFSG094 & C041T21410GUESG077 \\
\hline C032T11130GUFSG094 & U/A C041T11130GUESG065 & C041T11130GUFSG103 & C041T21410GUESG078 \\
\hline C032T11130GUFSG103 & T11130GUESG069 & C041T11130GUFSG112 & C041T41130GIA ISG032 \\
\hline
\end{tabular}

(b)

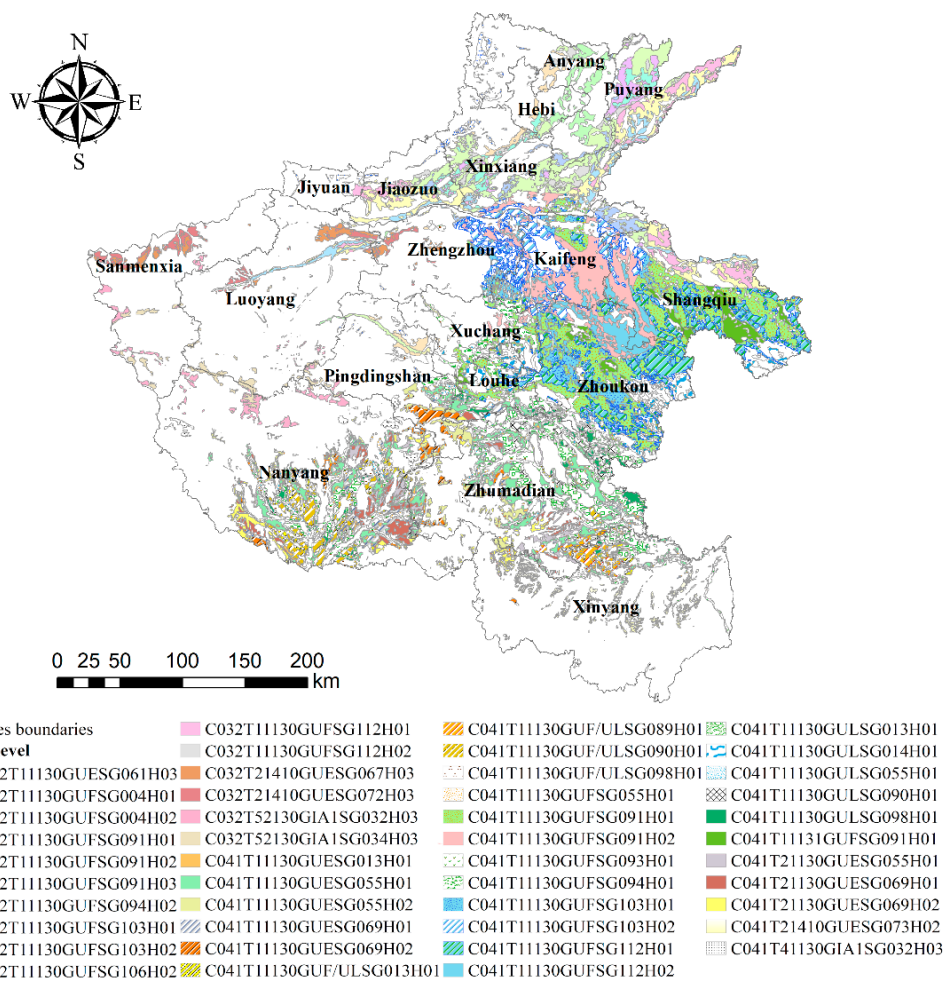

(c)

Figure 5. Distribution map of land types in Henan province. (a) Distribution map of first-level types, (b) distribution map of second-level types (top 45 by area proportion), and (c) distribution map of third-level types (top 45 by area proportion). 
Among the second-level units, the alluvial (fluvial) loamy fluvo-aquic soil of the uplift/erosion flow low-altitude plain in the northern subtropical humid region (C041T11130GUFSG091) accounts for the largest area ratio (6.71\%) in Henan, followed by alluvial (fluvial) loamy fluvo-aquic soil of the uplift/erosion flow low-altitude plain in the warm temperate semi-humid region (C032T11130GUFSG091), accounting for $4.31 \%$. In this level, the categories with high frequency are the aeolian loess cinnamon soil of the uplift/erosion flow low-altitude plain in the northern subtropical humid region (C041T11130GUESG069) and the aeolian sand-covered ginger black soil of the uplift/erosion flow low-altitude plain in the northern subtropical humid region (C041T11130GUESG013).

Among the third-level units, the shallow groundwater-alluvial (fluvial) loamy fluvoaquic soil of the uplift/erosion low-altitude plain in the northern subtropical humid region (C041T11130GUFSG091H01) accounts for the largest area ratio of Henan $(4.18 \%)$. Then, the middle-deep groundwater-alluvial soil of the uplift/erosion low-altitude plain in the northern subtropical humid region (C041T11130GUFSG091H02) accounts for 2.53\%. Shallow groundwater-alluvial (alluvial) clay fluvo-aquic soil of the uplift/erosion low-altitude plain in the northern subtropical humid region (C041T11130GUFSG112H01), shallow groundwater-lake fluvo-aquic soil of the uplift/erosion low-altitude plain in the northern subtropical humid region (C041T11130GULSG013H01), and middle-deep groundwateralluvial loam fluvo-aquic soil of the uplift/erosion low-altitude plain in the warm temperate semi-humid region (C032T11130GUFSG091H02) account for more than $2.00 \%$ of Henan.

\subsection{Analysis of Cultivated Land and Social Status in Henan Province}

In this study, the current situation of cultivated land, population, grain yield, and GDP data from 2009 to 2018 were used to analyze the development and change of land use in Henan province in the past 10 years. Overall, the area of cultivated land decreased by $4592.91 \mathrm{~km}^{2}$, while the resident population increased by 1.18 million. Grain yield increased from 57.69 million tons in 2009 to 66.49 million tons in 2018, and GDP increased from 1974.8 billion yuan in 2009 to 4836.8 billion yuan in 2018. It can be seen that during the past 10 years, the area of cultivated land has decreased, the population has increased, and the economy has developed rapidly, indicating that urban development has occupied cultivated land, which has reduced the area of cultivated land. The grain yield in 2018 of Henan province ranked second in China, and to ensure adequate grain, the degree of cultivated land reclamation has increased.

To understand the change of these factors, spatial barycenter transfer analysis based on ArcGIS software as used, and then the barycenter transfer map (Figure 6) and latitude and longitude changes of factors (Table 2) could be obtained. From the perspective of the province, the geometric center of Henan province is $113.61^{\circ} \mathrm{E}, 33.88^{\circ} \mathrm{N}$, located in Xiangcheng County, Xuchang City. The migration distance of cultivated land barycenter is small, and the overall migration direction is southeast, which shows that the cultivated land area in the northwest direction has reduced more in the past decade, while the migration distance of resident population is the largest, and the migration direction is northwest. Zhengzhou, as the capital city of Henan, is in the near direction of the migration of population barycenter and the far direction of the migration of cultivated land. The resident population of the whole province has increased; however, the barycenter deviates from the geometric center of Henan, and the population distribution is uneven. The center of GDP shifted to the northeast, indicating that the economic development in the eastern region is relatively rapid. The deviation of grain yield is small, moving northeastward, meaning that the eastern and southern regions of Henan have gradually become the main areas of grain production. 


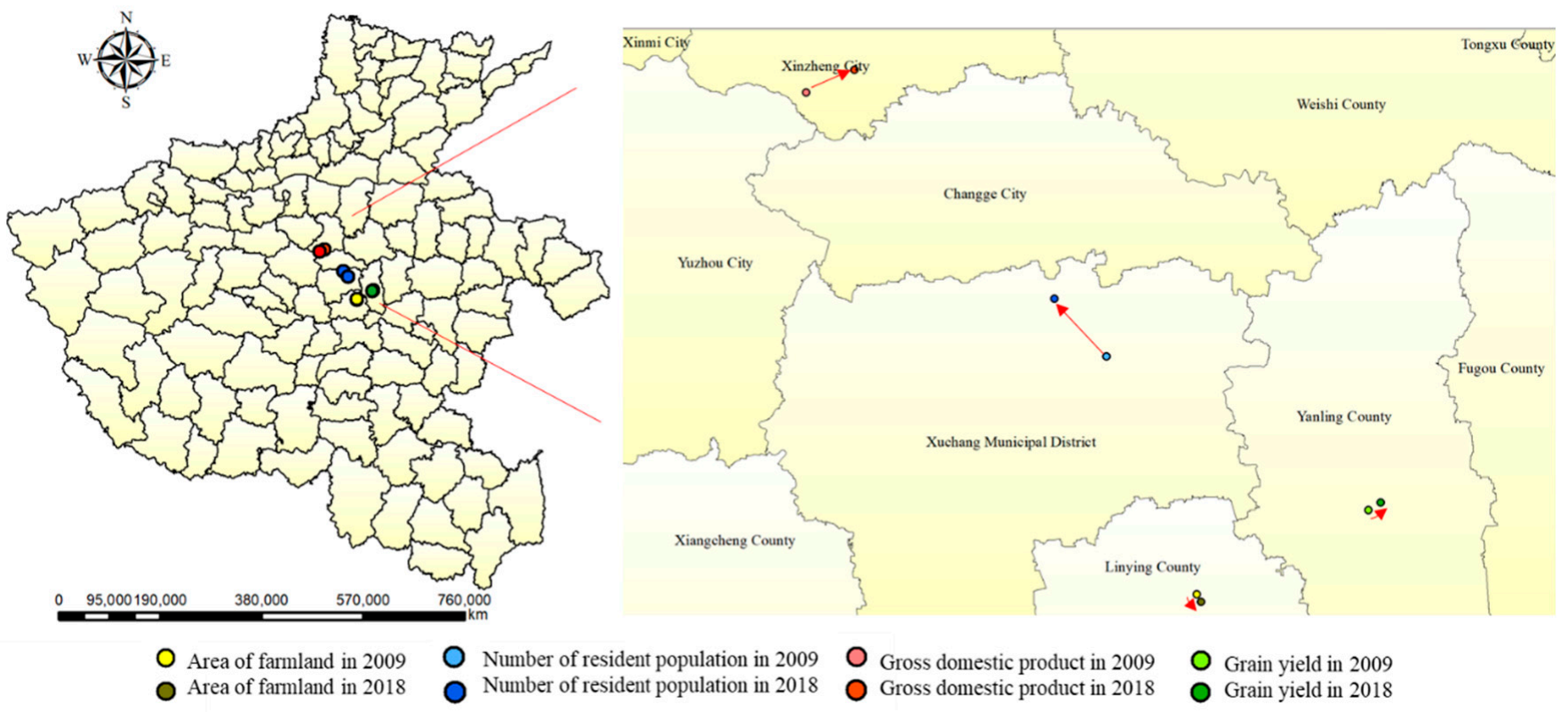

Figure 6. The barycenter transfer map.

Table 2. Barycenter transfer of two-period factors data from 2009 to 2018.

\begin{tabular}{lccccccc}
\hline Coordinate & Year & \multicolumn{2}{c}{2009} & \multicolumn{2}{c}{2018} & \multicolumn{2}{c}{ Barycenter Transfer during 2009 to 2018 } \\
\cline { 2 - 7 } Factor & X & Y & X & Y & Migration Direction & Migration Distance/m \\
\hline Cultivated land area & $114.01^{\circ} \mathrm{E}$ & $33.90^{\circ} \mathrm{N}$ & $114.02^{\circ} \mathrm{E}$ & $33.89^{\circ} \mathrm{N}$ & Southeast & 806.2198 \\
Resident population & $113.93^{\circ} \mathrm{E}$ & $34.09^{\circ} \mathrm{N}$ & $113.88^{\circ} \mathrm{E}$ & $34.14^{\circ} \mathrm{N}$ & Northwest & 7031.228 \\
GDP & $113.63^{\circ} \mathrm{E}$ & $34.31^{\circ} \mathrm{N}$ & $113.68^{\circ} \mathrm{E}$ & $34.33^{\circ} \mathrm{N}$ & Northeast & 4820.586 \\
Grain yield & $114.18^{\circ} \mathrm{E}$ & $33.97^{\circ} \mathrm{N}$ & $114.20^{\circ} \mathrm{E}$ & $33.98^{\circ} \mathrm{N}$ & Northeast & 1308.578 \\
\hline
\end{tabular}

From the perspective of cities in Henan province (Figure 7), the cultivated land area of Jiaozuo City increased by $682.29 \mathrm{~km}^{2}$, while other cities decreased, and the area of cultivated land in Zhengzhou City, Xuchang City, Luoyang City, and Nanyang City reduced more than others, and superimposed on the spatial database of land types, it can be seen that in 2009 and 2018, the places with reduced cultivated land area are located in the western part of Henan, with high altitude. The terrain of the western region in Luoyang City and Nanyang City is high and the rock type is granite, which is not suitable for planting crops. In terms of the resident population, the number in western and northern regions increased except for in Anyang City, while the resident population in southern and eastern regions decreased. GDP in all cities increased, while grain production decreased only in Zhengzhou and Xinyang City and increased in other cities. It reveals that the social and economic development of each city has promoted the expansion of the scale of construction, which has reduced the area of cultivated land. However, to ensure food security and increase the yield of cultivated land, it is inevitable that the cultivated land somewhere was excessively used. 


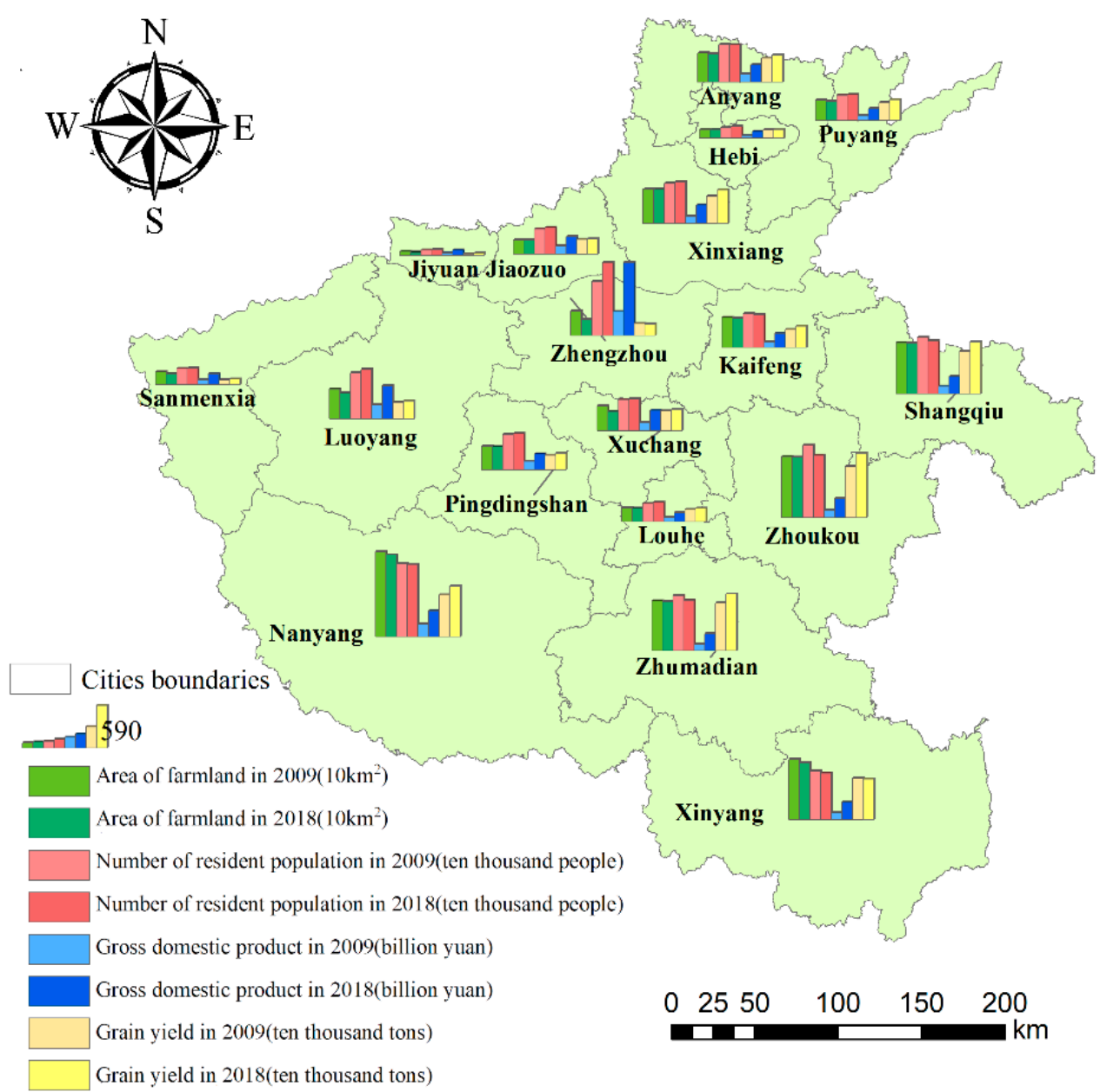

Figure 7. Changes of factors in different cities of Henan province from 2009 to 2018.

\subsection{Evaluation Results of Cultivability in Henan Province}

According to the evaluation method of cultivability, the relevant data were processed, and then the results of the cultivability evaluation in Henan province were divided into four categories (Figure 8) and the calculation results of cultivability in various cities were statistically analyzed (Table 3). The highly suitable area for farming in Henan is $8977.58 \mathrm{~km}^{2}$, accounting for $5.42 \%$ of the total area of Henan, mainly distributed in parts of the eastern and southern regions, in which Zhumadian City has the largest area (50.56\%), followed by Zhoukou City (10.24\%), Nanyang City (10.09\%), and Xinyang City (9.79\%). The moderately suitable area for farming is $92,600.23 \mathrm{~km}^{2}$, accounting for the largest proportion $(55.90 \%)$ of the total area of Henan, mainly distributed in the eastern, central, southern, northern, and southwestern regions and distributed in all the cities, in which Nanyang City has the largest area (19.98\%), followed by Xinyang City (17.13\%), Zhumadian City (10.05\%), and Zhoukou City (9.77\%). The marginally suitable area for farming is $56,228.52 \mathrm{~km}^{2}$, accounting for $33.94 \%$ of the total area of Henan, mainly distributed in most parts of the northern and western regions, and other areas have scattered distribution. Similarly, it is distributed in all cities, in which Luoyang City has the largest area (18.85\%), followed by Sanmenxia City (13.72\%) and Nanyang City (11.87\%). The area of unsuitable for farming is $7857.31 \mathrm{~km}^{2}$, accounting for $4.74 \%$ of the area of Henan, mainly distributed in the western and northwestern regions, in which Luoyang City has the largest area (33.39\%), followed by Sanmenxia City (22.76\%) and Nanyang City (14.26\%). 


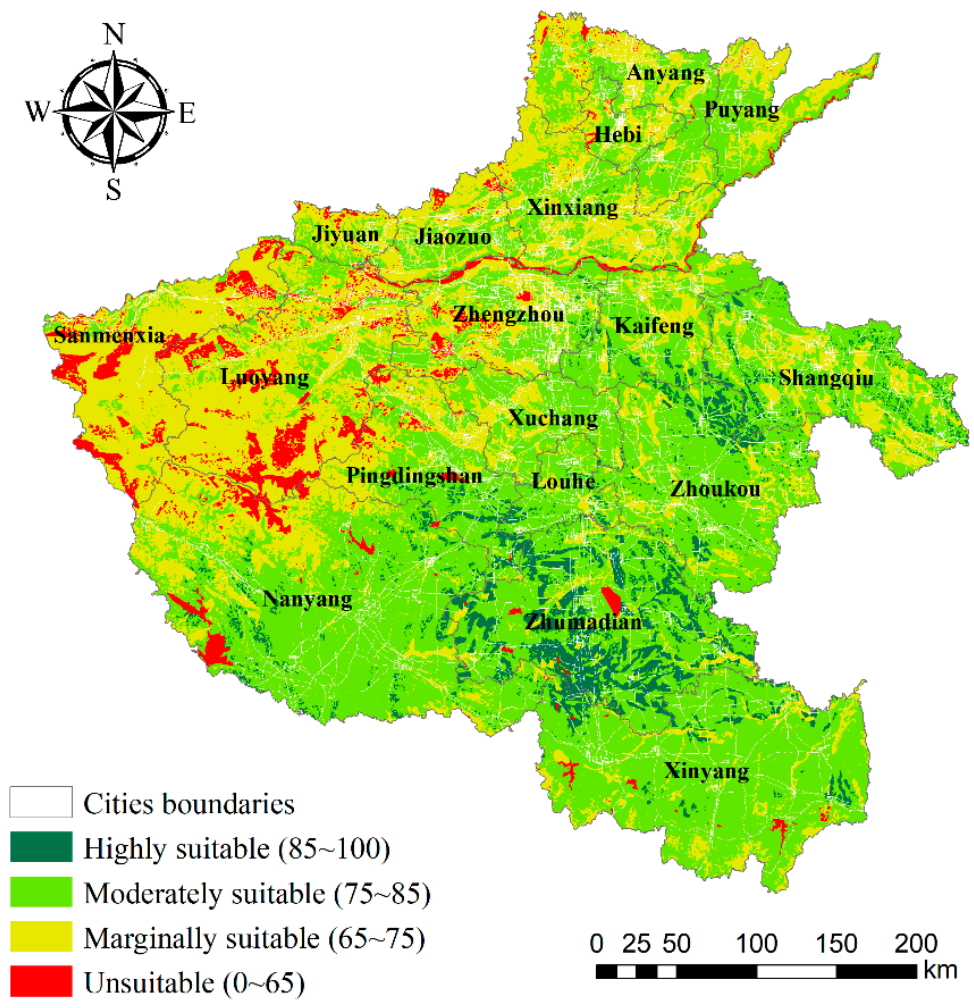

Figure 8. Spatial distribution of cultivability evaluation results in Henan province.

Table 3. Statistical table of cultivability evaluation area of cities in Henan province $\left(\mathrm{km}^{2}\right)$.

\begin{tabular}{ccccc}
\hline City & Highly Suitable & $\begin{array}{c}\text { Moderately } \\
\text { Suitable }\end{array}$ & $\begin{array}{c}\text { Marginally } \\
\text { Suitable }\end{array}$ & Unsuitable \\
\hline Zhengzhou & 58.79 & 3212.69 & 3081.71 & 653.30 \\
Kaifeng & 215.61 & 4279.27 & 1630.40 & 27.57 \\
Luoyang & 0.00 & 2461.99 & $10,599.88$ & 2623.40 \\
Pingdingshan & 454.62 & 4370.34 & 2656.22 & 382.99 \\
Anyang & 12.89 & 3601.66 & 3442.16 & 150.05 \\
Hebi & 0.23 & 1032.47 & 959.82 & 53.46 \\
Xinxiang & 29.58 & 3411.59 & 4422.52 & 219.61 \\
Jiaozuo & 2.22 & 1638.73 & 1992.15 & 174.04 \\
Puyang & 1.10 & 2318.94 & 1822.76 & 122.78 \\
Xuchang & 8.22 & 3424.63 & 1382.02 & 11.74 \\
Luohe & 182.35 & 2061.20 & 359.78 & 0.00 \\
Sanmenxia & 0.00 & 765.34 & 7711.74 & 1788.66 \\
Nanyang & 906.22 & $18,498.46$ & 6676.21 & 1120.19 \\
Shangqiu & 767.93 & 6688.41 & 3032.58 & 0.00 \\
Xinyang & 879.18 & $15,859.03$ & 2318.18 & 216.59 \\
Zhoukou & 919.18 & 9043.00 & 1922.36 & 0.99 \\
Zhumadian & 4539.46 & 9304.65 & 1075.35 & 197.68 \\
Jiyuan & 0.00 & 627.84 & 1142.67 & 114.28 \\
Sum & 8977.58 & $92,600.23$ & $56,228.52$ & 7857.31 \\
\hline
\end{tabular}

By overlaying the cultivability evaluation results with the spatial database of land types, it can be seen that the climate in the highly suitable areas basically belongs to the northern subtropical humid region. The altitude is low, and most of them are plains or platforms. The rock types are basically fluvial and lacustrine deposits. Among the soil types, there is sandy ginger black soil, alluvial yellow cinnamon soil, loess yellow cinnamon soil, loam fluvo-aquic soil, loam gray fluvo-aquic, and clay fluvo-aquic soil, 
and the groundwater depth is shallow. These places are suitable for farming from the natural conditions of climate, topography, geology, soil, and groundwater, and the social economy and management level of the highly suitable areas are at the upper-middle level. Compared with the highly suitable areas, the climate of the moderately suitable areas is mostly distributed in the northern subtropical humid region, and the others are distributed in the warm temperate semi-humid region and distributed from the low altitude plain to the undulating mountains; the rock types are basically granite, aeolian, alluvial (fluvial), and weathered debris. In addition to the soil with good quality at low altitude, the soil with low fertility at higher altitude is also distributed. The climate in the marginally suitable regions is mostly distributed in the warm temperate semi-humid region, and the other regions are distributed in the northern subtropical humid region and distributed from the low-altitude plain to the undulating mountains. However, compared with the moderately suitable areas, with the altitude increases, the types of rock and soil are gradually distributed towards the types that are not suitable for farming. In terms of social and economic management, the investment is reduced compared with the moderately suitable areas. The climate of the unsuitable areas basically belongs to the warm temperate semi-humid region with high altitude. The rock types are mainly granite, aeolian, limestone, and other carbonate rocks. The soil types are mainly calcareous coarse bone soil, calcareous cinnamon soil, siliceous yellow-brown soil, and siliceous aluminum neutral coarse bone soil. Due to the high altitude, groundwater has a deep depth; from the perspective of natural conditions, such areas are not suitable for farming, and from the perspective of social and economic management, the infrastructure is relatively weak and the investment is less. Therefore, according to the basic database of land types, the evaluation results of cultivability are in line with the current situation.

\subsection{Adaptive Management of Cultivated Land Use Zones in Henan Province}

According to the above land utilization zoning adaptive management scheme, the land suitable for farming in Henan can be divided into six management zones (Figure 9). Based on the basic database of land types and the analysis of cultivability evaluation, and according to regional characteristics and adaptive management objectives of cultivated land, we put forward corresponding management suggestions for different zones (Table 4).

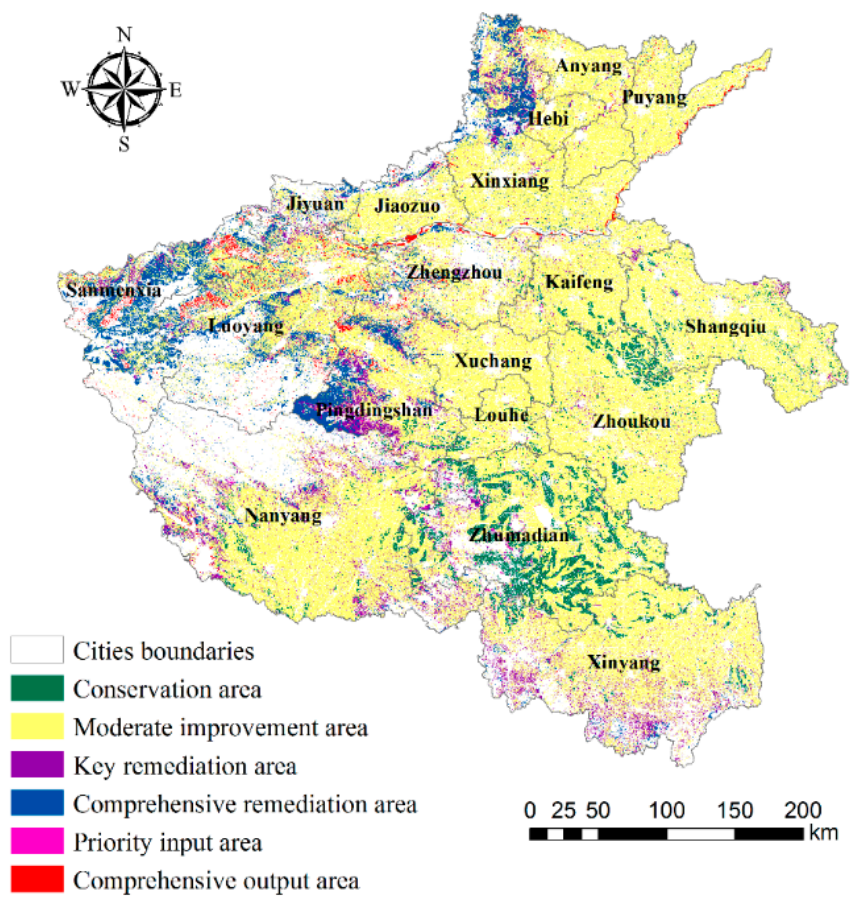

Figure 9. The zoning map for management and protection of land suitable for farming. 
Table 4. Adaptive management suggestions in different management zones.

\begin{tabular}{cc}
\hline Zone & Location \\
\hline Conservation area & Mainly located in the central, \\
southern, and eastern parts in \\
Henan, concentrated in \\
Zhumadian City and the northern \\
part of Zhoukou City, and \\
scattered in Shangqiu City, \\
Kaifeng City, Luohe City, \\
Pingdingshan City, Xinyang City, \\
and Nanyang City.
\end{tabular}

Regional Character

Widely distributed in Henan,

located in the northern, eastern,

central, and southern regions,

Moderate

improvement area except for Sanmenxia City, Jiyuan City, southern Luoyang City, and western and northern Nanyang City.

Key remediation area

Widely distributed in Henan, and is distributed in various cities, but it is concentrated in Pingdingshan City.
As widely distributed in

Henan, its regional characteristics cover the overall characteristics of Henan, there are certain limiting factors, but it is basically suitable for farming.
The climate in this area is mostly in the northern subtropical humid region, with low altitude, gentle terrain, good soil quality, and few restrictive factors, so it is a suitable for farming.

\section{Adaptive Management Suggestions}

Based on its favorable farming environment, continue to maintain a good farming state, and under the principle of maintaining the farming environment without damage, increase investment in farmland, optimize farmland layout, and build ecologically fertile land.

The current land use types in this area are basically mining land, garden land, facility agricultural land, and sparse forest land. These land use types can be transferred to cultivated land by adjusting the land use structure.

This area is currently used for farming, but due to certain restrictions, the quality of cultivated land needs to be improved.

According to the actual situation of the area, specific limiting factors can be identified, and one or two of the limiting factors can be improved to improve the quality of cultivated land.

The current land use types in this area are basically mining land, garden land, bare land, sparse forest land, etc. However, the natural, social, economic, and management conditions of cultivated land in this area are at an upper-middle level, and there are few restrictive factors. Need to analyze the specific methods to improve the quality of cultivated land, and can provide backup resource supply for the strategy of "grain storage in land and technology".

The current land use types in this area are basically mining land, garden land, bare land, facility agricultural land, and sparse forest land, etc., but they can be used for farming. Due to the high terrain and large slope, there will be certain difficulties in the utilization of cultivated land, and more investment is required, and then comprehensively renovate the area and reduce restrictions.

Mainly located in the western and
northern parts of Henan, and distributed in Pingdingshan City, Luoyang City, Sanmenxia City, Zhengzhou City, Anyang City.
The climate in this area is in the warm temperate semi-humid region, the altitude is high, the terrain has large fluctuations, the soil quality is general, and there are many limiting factors, but it can be used for farming.
Mainly located in the

Comprehensive output area northwestern part of Henan, and distributed in Sanmenxia City, Luoyang City, Zhengzhou City, Pingdingshan City, etc.
The climate in the region is mostly in the warm temperate semi-humid region, with high altitude, large undulating terrain, and poor soil quality, there are many limiting factors, and it is not suitable for farming.
The area is currently used for farming, but its natural conditions and socio-economic and management conditions are not suitable for farming. Based on the principle of protecting nature, the supply and demand of food should be comprehensively considered, and the cultivated land in this area can be appropriately transferred to other land use.

\section{Discussion}

China uses $7-8 \%$ of the world's agricultural land to feed nearly $22 \%$ of the world's population. The predatory use of cultivated land and the rapid urbanization process have caused a large loss of cultivated land and an extremely sharp contradiction between human and land resources. To coordinate food security, cultivated land protection, and the contradiction between human and land resources, China has implemented the strictest cultivated land protection system. However, in terms of the implementation effect of this system, although China's strict cultivated land protection system has curbed the loss of cultivated land to a certain extent, it has not fundamentally reversed the decreasing trend of the area of cultivated land [71], and the area of cultivated land has decreased 
and the quality has declined, as the ecological environment has been destructed [72], which is closely related to the unclear potential space of cultivated land in China. In 2015, China put forward the strategy of "grain storage in land and technology". Its connotation is to improve China's cultivated land quality and land productivity, improve the comprehensive grain production capacity, and at the same time pay attention to the ecological protection of cultivated land, avoid excessive consumption of cultivated land, and coordinate the production space of cultivated land while ensuring food supply [73]. Therefore, under the influence of COVID-19, a clear potential space guarantee can better protect the implementation of China's food security.

Henan province is one of the major grain-producing provinces in China, and for many years, the total grain output has ranked second. From the analysis of cultivated land use and socio-economic output of Henan from 2009 to 2018, the cultivated land area of Henan had decreased, but the grain output had increased. It can be seen from the relevant literature on the dynamic change of cultivated land use in Henan province that the cultivated land in Henan is decreasing year by year, mainly due to the improvement of the urbanization level and the implementation of policies such as returning farmland to forest and grassland [74,75]. To ensure sufficient food, the reclamation degree of cultivated land had increased, which has led to overexploitation to a certain extent. Therefore, the issues of cultivated land in Henan are worthy of attention. Is the land suitable for farming in places where land was once cultivated, are there any conditions that can be converted to cultivated land, and what is the suitability of existing cultivated land?

In order to solve the above issues and achieve sustainable development, it is necessary to identify the potential space of cultivated land according to local conditions, set differentiated control measures for different cultivated land use conditions, take the available cultivated land as the reserved land for flexible control of cultivated land, and protect the existing cultivated land, which is a reasonable and achievable path to sustainable development. The "adjusting measures to local conditions" means considering the use of land on the basis of the natural background attribute of land. Obviously, land type is an effective tool to reflect this attribute. However, the domestic research on the division of land types has made little substantive progress since the mid-1980s, and the research has been interrupted. Moreover, most of the past research was based on the cognition of that time; at present, with the increase of land development, the division of land types needs to be based on the concept of the current land system, considering the research purpose and the key restrictive factors on cultivated land. Therefore, based on the previous research, this study combined the hydrological factors that have an important impact on crop growth, which is in line with the demand of determining land by water in green sustainable and high-quality development.

Based on the current research needs, this study establishes a provincial-level land types classification system and makes practical application in Henan province. From the lowest level classification unit of land type, each type unit can reflect the attributes of climate, landform, rock type, soil type, and groundwater depth. The results of land types are applied to the evaluation of cultivability, considering the connection between the factors of land type divisions and the existing evaluation index system of cultivability, the evaluation system of cultivability based on land types is constructed. Through the mutual verification between the results of land types and the evaluation results of cultivability, the application of land types in cultivability evaluation is expanded, which improves the dissatisfaction with older methods that only take the current land use status as the evaluation object in land suitability evaluation, and takes it as the basis for identifying the potential space of cultivated land. The idea of this study is a practical, operable, and effective implementation path that can meet the current national strategy of "grain storage in land and technology".

However, there are also some deficiencies in this study. After the analysis of arable land suitability, optimizing the utilization status, and carrying out different zoning management and protection analyses, it still needs time to optimize the land layout. How to reasonably arrange the optimization mode in time sequence and adjust the land structure according to 
different development modes, such as population growth, land use change, or emergency mode, and then putting forward more adaptive management measures under different modes is a more effective research way of resource management and protection, which is also the key direction of future research.

\section{Conclusions}

Based on the traditional land types classification, we regarded land as a natural system from the perspectives of land geography and systematics and established a "top-bottom" hierarchy, a three-level land type classification system at the provincial level from five aspects-climate, topography, geology, soil properties, and hydrological conditions, which is an effective application of the current nature-based solution concept in the research of land type classification. The results can be applied to various land use practices to analyze the existing problems of land use based on the natural attributes.

From 2009 to 2018, the area of cultivated land in Henan decreased, but the grain output increased, the degree of cultivated land reclamation increased, and the eastern and southern regions gradually became the main areas of grain production. Highly suitable areas are mainly located in the east and south of Henan, moderately suitable areas are mainly located in the east, middle, south, north, and southwest, marginally suitable areas are mainly located in most areas of the north and west, and unsuitable areas are mainly located in the west and northwest. Different suitable areas have different corresponding land types and the areas with high suitability, where the attribute of its land type is more suitable for agricultural production.

According to the evaluation results of cultivability based on the land types and superimposed the status of land use, we analyzed the land use types that can be adjusted, then we proposed the cultivated land zoning adaptive management scheme. Six management zones-conservation area, priority input area, moderate improvement area, key remediation area, comprehensive remediation area, and comprehensive output area-were divided in Henan, and corresponding management suggestions were put forward according to the characteristics of different zones. The analysis and judgment of suitable land for farming combined with the land types classification plays an important role in regional sustainable development and can effectively identify the mismatched land and the elastic space of cultivated land, which can provide reference for the transformation of cultivated land management measures in China from "balance of occupation and compensation" to "balance of input and output".

Author Contributions: Conceptualization, Y.L. and K.W.; Data curation, Y.L.; Formal analysis, Y.L. and H.C.; Funding acquisition, K.W.; Methodology, Y.L. and X.L. (Xiaoliang Li); Project administration, K.W.; Software, Y.L., X.L. (Xiaoliang Li), and X.L. (Xiao Li); Writing-original draft, Y.L.; Writingreview and editing, Y.L., X.L. (Xiaoliang Li), X.L. (Xiao Li), and H.C. All authors have read and agreed to the published version of the manuscript.

Funding: This study was supported by the National Natural Science Foundation of China (42171261) and the National Key R\&D Program of China (No. 2018YFE0107000).

Institutional Review Board Statement: Not applicable.

Informed Consent Statement: Not applicable.

Data Availability Statement: The datasets used and/or analyzed during the current study are available on request from the first author.

Conflicts of Interest: The authors declare that they have no conflict of interest. 


\section{References}

1. FAO. The state of the world's land and water resources for food and agriculture-Systems at breaking point. In Synthesis Report; Food and Agriculture Organization of the United Nations: Rome, Italy, 2021. [CrossRef]

2. FAO; IFAD; UNICEF; WFP; WHO. The state of food security and nutrition in the world 2021. In Transforming Food Systems for Food Security, Improved Nutrition and Affordable Healthy Diets for All; Food and Agriculture Organization of the United Nations: Rome, Italy, 2021. [CrossRef]

3. Liang, X.Y.; Jin, X.B.; Yang, X.H.; Xu, W.Y.; Lin, J.H.; Zhou, Y.K. Exploring cultivated land evolution in mountainous areas of southwest China, an empirical study since the 1980s. Land Degra. Dev. 2020, 32, 546-558. [CrossRef]

4. $\quad$ Liang, X.Y.; Jin, X.B.; SUN, R.; Zhang, X.L.; Li, H.B.; Zhou, Y.K. Optimal allocation of land resources and its key issues from a perspective of food security. J. Nat. Res. 2021, 36, 3031-3053. [CrossRef]

5. Blazy, J.M.; Causeret, F.; Guyader, S. Immediate impacts of COVID-19 crisis on agricultural and food systems in the Caribbean. Agr. Syst. 2021, 190, 103106. [CrossRef]

6. Zheng, W.W.; Ke, X.L.; Xiao, B.Y.; Zhou, T. Optimising land use allocation to balance ecosystem services and economic benefits: A case study in Wuhan, China. J. Environ. Manag. 2019, 248, 109306. [CrossRef]

7. He, C.Y.; Liu, Z.F.; Xu, M.; Ma, Q.; Dou, Y.Y. Urban expansion brought stress to food security in China: Evidence from decreased cropland net primary productivity. Sci. Total Environ. 2017, 576, 660-670. [CrossRef]

8. Shen, R.F.; Chen, M.J.; Kong, X.B.; Li, Y.T.; Tong, T.N.; Wang, J.K.; Li, T.; Lu, M.X. Conception and evaluation of quality of arable land and strategies for its management. Acta Pedol. Sin. 2012, 49, 1210-1217.

9. Kong, X.B. Transition objectives, contents and ways of cultivated land protection in China under the background of rehabilitation system. J. Soc. Sci. Hunan Norm. Univ. 2021, 50, 1-12.

10. Liu, Y.S.; Qiao, L.Y. Innovating system and policy of arable land conservation under the new-type urbanization in China. Econ. Geogr. 2014, 34, 1-6.

11. Lambin, E.F.; Meyfroidt, P. Global land use change, economic globalization, and the looming land scarcity. Proc. Natl. Acad. Sci. USA 2011, 108, 3465-3472. [CrossRef]

12. Akpoti, K.; Kabo-bah, A.T.; Zwart, S.J. Agricultural land suitability analysis: State-of-the-art and outlooks for integration of climate change analysis. Agric. Syst. 2019, 173, 172-208. [CrossRef]

13. Zonneveld, I.S. The land unit-a fundamental concept in landscape ecology, and its applications. Landsc. Ecol. 1989, 3, 67-86. [CrossRef]

14. Zhao, S.Q. China's 1:1 Million Land Types Mapping Specification; Surveying and Mapping Press: Beijing, China, 1989.

15. Sun, Z.; Jia, S.F.; Yan, J.B.; Zhu, W.B.; Liang, Y. Study on the matching pattern of water and potential arable land resources in China. J. Nat. Resour. 2018, 33, 2057-2066.

16. Shen, Y.C. Studies on land types: Academic significance, function and prospect. Geogr. Res. 2010, $29,575-583$.

17. Rambanapasi, C.O. The concept of 'region' in the socio-spatial sciences: An instance of the social production of nature. Soc. Epistemol. 1993, 7, 147-182. [CrossRef]

18. Richter, D.B.; Billings, S.A. ‘One physical system': Tansley's ecosystem as Earth's critical zone. New Phytol. 2015, $206,900-912$. [CrossRef]

19. Van Engelen, V.W.P.; Dijkshoorn, J.A. Global and national soils and terrain digital databases (SOTER). In Report-ISRIC World Soil Information; World Soil Information: Wageningen, The Netherlands, 2013.

20. NRCS. Land resource regions and major land resource areas of the United States, the Caribbean, and the Pacific Basin. In NRCS Agricultural Handbook 296; USDA: Washington, DC, USA, 2006.

21. Ecological Stratification Working Group. A National Ecological Framework for Canada; Research Branch Agriculture and Agri-Food Canada: Ottawa, ON, Canada, 2017; ISBN 978-0-660-24501-0.

22. Liu, Y.N.; Wu, K.N.; Li, X.L.; Li, X. Land-type classification at provincial level based on GIS and fuzzy SOFM model: A case study of Henan province. China Land Sci. 2021, 35, 112-122.

23. Zhao, S.Q.; Shen, Y.C. Land classification system for 1:1 million in China and 1:2 hundred thousand land type maps in key provinces (autonomous regions) (draft). Nat. Res. 1980, 03, 13-24.

24. Zhao, S.Q. China's 1:1 Million Land Types Division and Mapping; Science Press: Beijing, China, 1986.

25. Zhang, F.R. Carrying out research on natural classification of land and accurately serving natural resource management. China Natural Resources, 2 August 2018; 1-2.

26. Zhao, H.F.; Wu, K.N. Discussion of soil survey, land type, and cultivated land evaluation-based on academic thought of Mr. Ni Shaoxiang's land Evaluation. Chin. J. Agric. Resour. Reg. Plan. 2021, 42, 245-252.

27. National Research Council. Basic Research Opportunities in Earth Science; National Academy Press: Washington, DC, USA, 2001.

28. Zhang, G.L.; Song, X.D.; Wu, K.N. A classification scheme for Earth's critical zones and its application in China. Sci. China Earth Sci. 2021, 64, 1709-1720. [CrossRef]

29. Lü, Y.H.; Hu, J.; Fu, B.J.; Harris, P.; Wu, L.H.; Tong, X.L.; Bai, Y.F.; Comber, A.J. A framework for the regional critical zone classification: The case of the Chinese Loess Plateau. Natl. Sci. Rev. 2019, 6, 14-18. [CrossRef]

30. FAO. Land Evaluation-Towards a Revised Framework. 2007. Available online: http://www.fao/ag/agl/public.stm (accessed on 10 June 2020). 
31. Yang, J.; Liu, Y.X.; Wang, S.H. An overview of the methods of GIS-based land-use suitability analysis. In Geoinformatics 2007: Geospatial Information Technology and Applications; SPIE: Nanjing, China, 2007; Volume 6754, pp. 1110-1120.

32. He, Y.B.; Yao, Y.M.; Chen, Y.Q.; Ongaro, L. Regional Land suitability assessment for tree crops using remote sensing and GIS. In 2011 International Conference on Computer Distributed Control and Intelligent Environmental Monitoring; IEEE Computer Society: Washington, DC, USA, 2011; pp. 354-363.

33. FAO. A FramEwork for Land Evaluation; FAO Soils Bulletin No.32 and ILRI publication NO.22.: Italy, Rome, 1976.

34. Shi, Y.L. Thirty years of research on land resources. Nat. Resour. 1986, 03, 54-57.

35. Bidadi, M.J.; Kamkar, B.; Abdi, O.; Kazemi, H. Land suitability analysis on rainfed wheat cropping using geospatial information systems (a case study: Qaresoo Basin). J. Agric. Sci. 2015, 25, 131-143.

36. Gautam, D.; Parul, P.; Manik, H.K. Agriculture land suitability evaluation for wheat cultivation using geomatics for Patan District, India. Intl J of Agric. Resour. Gov. Ecol. 2017, 13, 91-108.

37. Akinci, H.; Özalp, A.Y.; Turgut, B. Agricultural land use suitability analysis using GIS and AHP technique. Comput. Electron. Agr. 2013, 97, 71-82. [CrossRef]

38. Mosleh, Z.; Salehi, M.H.; Fasakhodi, A.A.; Jafari, A.; Mehnatkesh, A.; Borujeni, I.E. Sustainable allocation of agricultural lands and water resources using suitability analysis and mathematical multi-objective programming. Geoderma 2017, 303, 52-59. [CrossRef]

39. Murray, T.; Roger, P.; Sinton, D.; Steinitz, C.; Toth, R.; Way, D. Honey Hill: A Systems Analysis for Planning the Multiple Uses of Controlled Water Areas; Harvard Univ Cambridge Mass Dept of Landscape Architecture. 1971. Available online: https:/ / apps.dtic.mil/sti/citations / AD0736343 (accessed on 20 January 2022).

40. Malczewski, J. GIS-based land-use suitability analysis: A critical overview. Prog. Plann. 2019, 62, 3-65. [CrossRef]

41. Jiao, L.M.; Liu, Y.L. Model of land suitability evaluation based on computational intelligence. Geo-Spat. Inform. Sci. 2007, 10, 151-156. [CrossRef]

42. Gong, J.Z.; Liu, Y.S.; Chen, W. Land suitability evaluation for development using a matter-element model: A case study in Zengcheng, Guangzhou, China. Land Use Poli. 2012, 29, 464-472. [CrossRef]

43. Liu, L.M. Land Resources Science, 5th ed.; China Agricultural University Press: Beijing, China, 2010.

44. Wang, W.M. Land Resource Management, 2nd ed.; Higher Education Press: Beijing, China, 2010.

45. Fu, B.J.; Wang, S.; Zhang, J.Z. "Classification-Organization-Collaboration” the path to accelerate the global realization of SDGs. China Sustain. Tribune. 2019, Z2, 21-22.

46. Shen, Y.C.; Cheng, W.M.; Zhu, H.Y.; Jiang, G.H. Empirical study of basic classification and index system of land types in Beijing. Geogr. Res. 2013, 32, 1979-1986.

47. Bertalanffy, L.V. General System Theory_Foundations, Development and Applications; Tsinghua University Press: Beijing, China, 1987.

48. Gerald, M. Systems Thinking (Volume I): General Systems Theory, Cybernetics and Complexity; SAGE Publications: New York, NY, USA, 2003.

49. Ni, S.X. Introduction to Land Type and Land Evaluation; Higher Education Press: Beijing, China, 2009.

50. Capotorti, G.; Guida, D.; Siervo, V.; Smiraglia, D.; Blasi, C. Ecological classification of land and conservation of biodiversity at the national level: The case of Italy. Biol. Conserv. 2012, 147, 174-183. [CrossRef]

51. Shen, Y.C.; Wang, X.H.; Yue, Y.J. Analysis of ecological suitability and rational ecological system structure of land types: A case study in Zhengning County, Gansu Province. Prog. Geog. 2012, 31, 561-569.

52. Wang, Q.B. Land Resources Science, 2nd ed.; China Agricultural Publication Press: Beijing, China, 2011.

53. Gong, Z.T.; Zhang, G.L.; Chen, Z.C. Pedogenesis and Soil Taxonomy; Science Press: Beijing, China, 2007.

54. Li, Y.; Yu, X.B.; Liu, Y.; Zhang, G.S.; Zhang, Q.J.; Duan, H.L. Response of wetland plant functional traits to hydrological processes: A review. Chin. J. Ecol. 2018, 37, 952-959.

55. Yan, J.S.; Manfred, F. Trends and variability in streamflow and snowmelt runoff timing in the southern Tianshan Mountains. J. Hydrol. 2018, 557, 173-181.

56. Collins, M.G.; Steiner, F.R.; Rushman, M.J. Land-use suitability analysis in the United States: Historical development and promising technological achievements. Environ. Manag. 2001, 28, 611-621. [CrossRef]

57. Al-Mashreki, M.H.; Atroosh, K.B.; Muflahi, A.A.; Obaid, N.A.; Caoline, K. GIS-based assessment of land suitability for industrial crops (cotton, sesame and groundnut) in the Abyan Delta, Yemen. Am. J. Exp. Agric. 2015, 8, 384-405. [CrossRef]

58. Taghizadeh-Mehrjardi, R.; Nabiollahi, K.; Leila, R.; Ruth, K.; Scholten, T. Land suitability assessment and agricultural production sustainability using machine learning models. Agronomy 2020, 10, 573. [CrossRef]

59. Kazemi, H.; Akinci, H. A land use suitability model for rainfed farming by multi-criteria decision-making analysis (MCDA) and geographic information system (GIS). Ecol. Eng. 2018, 116, 1-6. [CrossRef]

60. Zhao, Q.G.; Yang, Z.S.; He, Y.M.; Yang, L.F. Cultivated land suitability evaluation based on land change investigation in 1996-2008 in mountainous areas at China's southwest border land-A case study in Yunnan province. In China's Land Resources Exploitation and Man-Land Harmonious Development in Mountain Areas; Science and Technology of China Press: Beijing, China, 2010; pp. 224-239.

61. Shi, T.G.; Zheng, G.Q.; Wang, Z.Y.; Wang, L.L. Progress in research on land suitability evaluation in China. Prog. Geog. 2007, 26, 106-115.

62. Amini, S.; Abbas, R.; Mohammad, H.A.; Mohammad, H.A.-F.; Mohammad, R.A. Assessment of land suitability and agricultural production sustainability using a combined approach (Fuzzy-AHP-GIS): A case study of Mazandaran province, Iran. Inform. Process Agric. 2020, 7, 384-402. [CrossRef] 
63. Bock, M.; Gasser, P.Y.; Pettapiece, W.W.; Brierley, A.J.; Bootsma, A.; Schut, P.; Neilsen, D.; Scott Smith, C.A. The Land Suitability Rating System Is a Spatial Planning Tool to Assess Crop Suitability in Canada. Technol. Rep. Front. Environ. Sci. $2018,6,77$. [CrossRef]

64. Hai, L.T.; Gobin, A.; Hens, L. Select indicators and prioritize solutions for desertification and drought in Binh Thuan, Vietnam. Chin. J. Popul. Resour. Environ. 2016, 14, 123-132. [CrossRef]

65. Ministry of Agriculture of the People's Republic of China. Cultivated Land Quality Grade (GB/T33469-2016); Standards Press of China: Beijing, China, 2016.

66. Ministry of Agriculture of the People's Republic of China. Rules for Soil Quality Survey and Assessment (NY/T 1634-2008); Standards Press of China: Beijing, China, 2008.

67. Ministry of Land and Resources of the People's Republic of China. Regulation for Gradation on Agriculture Land Quality (GB/T 28407-2012); Standards Press of China: Beijing, China, 2012.

68. Zheng, J.Y.; Bian, J.J.; Ge, Q.S.; Hao, Z.X.; Yin, Y.H.; Liao, Y.M. The climate regionalization in China for 1981-2010. Chin. Sci. Bull. 2013, 58, 3088-3099.

69. Zhou, C.H.; Cheng, W.M.; Qian, J.K.; Li, B.Y.; Zhang, B.P. Research on the classification system of digital land geomorphology of 1:1,000,000 in China. J. Geo-Inf. Sci. 2009, 11, 707-724.

70. Fan, Y.; Li, H.; Miguezmacho, G. Global patterns of groundwater table depth. Science 2013, 339, 940-943. [CrossRef]

71. Zhang, Y.M. Study on the transformation and countermeasures of cultivated land protection system-construction of the incentive system of protection of cultivated land. Chin. J. Agri. Resour. Reg. Plan. 2010, 20, 153-158.

72. Tan, S.k.; Zhang, H.X. Performance Evaluation on the policies of cultivated land protection in China from the perspective of quantity protection. China Popul. Resour. Environ. 2010, 20, 153-158.

73. Chen, Y.J.; Yi, X.Y.; Chen, J.Q.; Chen, Z.Q.; Han, W.; Yang, R.Z. Strategic and path selection of "Storing Grain in Arabile Land". Chin. J. Agri. Resour. Reg. Plan. 2016, 37, 8-14.

74. Lv, H.; Guo, X.B.; Zhao, W.D. Characteristics and spatial patten of land use change in Henan Province. Chin. J. Agri. Resour. Reg. Plan. 2017, 38, 142-145.

75. Liu, Y.N.; Wu, K.N.; Cao, H.L. Land-use change and its driving factors in Henan province from 1995 to 2015. Arab. J. Geosci. 2022, 15, 247. [CrossRef] 